\title{
WATER GOVERNANCE PERFORMANCE ASSESSMENT OF RIPARIAN COMMUNITIES: A CASE STUDY OF THE VOLTA RIVER BASIN
}

\author{
ABDUL-RAZAK ZAKARIA \& KENICHI MATSUI \\ University of Tsukuba, Japan
}

\begin{abstract}
Governance inefficiencies can exacerbate flooding in developing countries and regions where flood protection infrastructures are particularly weak. This is the case in the Volta Basin of western Africa where irregular flood-drought cycles have devastated the livelihoods of riparian communities. It is critical to know how water governance can better respond to floods. This paper assesses water governance performance in the Volta Basin, especially Burkina Faso-Ghana border areas. The discussion is largely based on our original questionnaire survey that sought to understand riparian perceptions and needs regarding four key water governance principles: public participation, gender equity, transparency and regulatory quality. With a five-point Likert-scale, we sought respondents' level of agreement and or satisfaction regarding statements about these governance principles. Regarding public participation, the results show that $49 \%$ of the respondents in Ghana and $42 \%$ of those in Burkina Faso thought that their communities were not sufficiently engaged in program implementation. Concerning transparency, $54 \%$ and $55 \%$ in Ghana thought that it was easy to access information and that decision-making processes were easy to understand. In Burkina Faso, 59\% felt it difficult to access information, and $63 \%$ was not sure whether decision making processes were easily understood. With regards to regulatory quality, $58 \%$ of the respondents in Ghana and $54 \%$ of those in Burkina Faso were satisfied with regulatory quality. On gender equity, $72 \%$ in Ghana and $78 \%$ in Ghana Burkina Faso found it challenging. These findings are discussed in a socio-economic context to illustrate the current status of water governance in the study areas. Based on these findings, we discuss how transboundary water governance in Africa may become more efficient in the future.

Keywords: water governance, public participation, gender equity, transparency, regulatory quality, Volta River Basin, riparian communities’ perceptions, assessment, Burkina Faso, Ghana.
\end{abstract}

\section{INTRODUCTION}

Amid a global trend of increasing water demand FAO [1] and water related disasters, governance solution has gained much attention [2]-[4]. UN-Water stated that "water crisis is essentially a crisis of governance" [5]. The FAO also included water governance as one of four components of food security [6].

Global Water Partnership [7] defined water governance as the "spectrum of political, social, economic and management structures in the development and management of water resources and water services across different levels of society" [8]. Other definitions of water governance highlight the importance of how decisions are made, by whom, and under what conditions [6], [9]-[12].

Kaufmann et al. [13] reported strong causal relationships between better governance and better development outcomes. Hanasz [14] maintained that good water governance encourages stakeholder participation in decision-making and engenders accountability. Rogers and Hall [8] argued that effective or good water governance can be achieved when all relevant sectors actively participate in decision-making.

Among the most contentious water governance issues is related to the development and operation of large dams that often-deprived downstream regions or countries of reasonable water flow. Lower stream communities also suffered from irregular flood damage due to 
spillage from dams [15]-[18]. Because of these problems, in the last ten years rising political tensions have been observed between riparian communities in Ghana and Burkina Faso. Although this governance issue can affect more than 20 million people in western Africa by 2050, we do not know much about how governance can be a solution to these rising tensions. This paper, therefore, attempts to assess water governance performance in the Volta River Basin, especially between these two countries. In particular, as rising tensions have been incubated among local communities, it focuses on perspectives of riparian communities with particular focus on such salient governance aspects as public participation, transparency, gender equity and the quality of regulations.

\section{CRITERIA FOR GOOD WATER GOVERNANCE}

Our examination of these four principles for the purpose of assessing water governance performance was based largely on rich sources of past studies. Rogers and Hall [8] examined operational, organizational, and constitutional levels of governance. The organizational level coordinates and reduces conflicts between competing water interests. It also enforces rules and polices for water usage and users. Here they identified public participation, transparency, gender equity and the quality of regulations as essential components.

International water governance organizations and scholars have recognized the importance of appropriate public participation and transparency in water governance practices. The International Commission for the Protection of the Rhine (ICPR), for instance, noted that good transboundary cooperation in the Rhine was due partly to the long tradition of cooperation among stakeholders [19]. Paul et al. [20] reiterated that public participation offers a voice for all actors in decision making. Good governance requires transparent decision-making processes that ensure traceability of the process by internal and external actors [8]. Transparency enhances public knowledge and access to information. It also promotes accountability [9].

Equal representation and benefit sharing among various stakeholders in the policy development and implementation process ensures fairness [8]. Good water governance must address gendered issues [9].

Regulatory quality determines the accountability of governance practices. Good accountability reassures the public about institutional and administrative framework to address fair, equitable, and transparent processes. Under good regulations, water administrations are required to act to address complaints and requests from stakeholders [9], [20].

Scholars and international organizations have attempted to assess the level of good governance by employing a set of criteria. Pre-requisite conditions of good governance for some scholars included inclusiveness, consensus-making arrangement, accountability, participation, transparency, responsiveness, equity and inclusiveness, effectiveness and efficiency, and lawfulness [8], [14]. The UNDP (1997) proposed that good governance should be assessed by 10 criteria: public participation, consensus orientation, strategic vision, responsiveness, effectiveness, efficiency, accountability, transparency, equity, and rule of law [20]. The Global Water Partnership similarly emphasized openness, transparency, participation, accountability, effectiveness, coherence, efficiency, communication, equity, integration, sustainability, and ethics [12]. Mahon et al. [21] proposed to assess transboundary water governance by governance architecture, governance processes, social justice, ecosystem pressure, stakeholder engagement, ecosystems state, and human wellbeing. 
Some of these criteria were further examined in past studies. Public participation, for example, was assessed by local needs, facilitating conditions, legal frameworks, equity, and decision-making. Equity in water governance was assessed by gender-roles, the performance of water institutions, and justice. The assessment of transparency was done on the basis of public knowledge dissemination, information access for decision-making, openness about processes, and information sharing. Accountability was assessed by regulatory reform (e.g., anti-corruption measures), institutional actions and performance, and public opinion about responsible authorities [9], [20], [22].

The performance level of water governance was assessed by indicators. For instance, Mahon et al. [21] proposed a new Transboundary Waters Governance Assessment Framework. It contains seven somewhat overlapping indicators: governance architecture, governance process, stakeholder engagement, social justice, ecosystem pressure, ecosystem state and human well-being. It then determined the level of governance architecture by the existence of governance procedures. Governance processes were evaluated by plans and function. Stakeholders' engagement was strongly linked to the capacity development of the public for effective engagement. Social justice meant equity. Ecosystem pressure was measured by the extent to which some policies resulted in behavioral changes in favor of environmental conservation. Ecosystem's state was described in terms of whether changes in behaviors resulted in environmental conditions. Human well-being was linked to both social justice and the sustainability of ecosystem goods and services that, in turn, benefit people.

\section{STUDY AREA}

In order to assess water governance performance, this paper provides a case study on a transboundary region of the Volta River Basin, one of the largest and most important river basins in west Africa (Fig. 1). We chose three riparian communities each along the Volta River that runs through Burkina Faso and Ghana. In Ghana, we looked at the Bawku zone in the Upper East Region. In Burkina Faso, we examine Bagre district in the Eastern Central Region where Bagre Dam is located. Our preliminary field visit to these areas made us choose these communities to focus on flood damage due to the dam spillage.

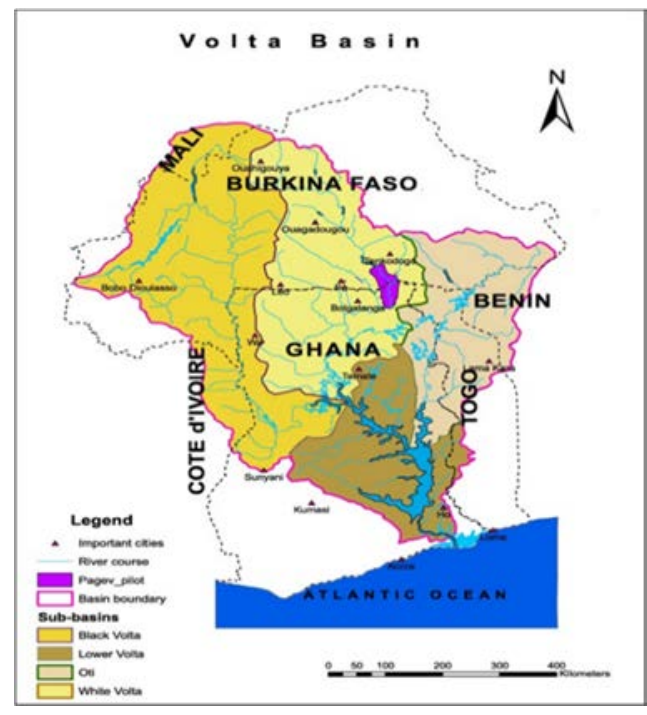

Figure 1: Volta River Basin [30]. 
The Bawku zone consists of six administrative districts, of which four districts are directly affected by Volta River flows. These districts are Binduri, Garu, Bawku Municipality and Bawku West districts. We selected three communities from these districts as these were considerably affected by dam spillage in the past. These three districts also have similarities in terms of climate, soil type, farming system, culture, language and the crops grown [23][25]. Here the climate is characterized by the wet season from May to October and the dry season from November to April. The total population in the three selected districts was 290,117 according to the 2010 population and housing census. Average annual rainfall ranges from $950 \mathrm{~mm}$ to $1,100 \mathrm{~mm}$. Vegetation here is the Sahel Savannah type with scattered shrubs, short grasses, and trees. Agriculture is the mainstay with such major food crops as maize, rice, sorghum, pepper, watermelon, and onion. Farmers draw water from the Volta River [23]-[26].

Bagre is one of administrative districts of Burkina Faso's Eastern Central Region. It is located below the Bagre dam area [27]. The climate is characterized by dry (harmattan) and wet (rainy) seasons. Annual rainfall ranges between 850 to $1,100 \mathrm{~mm}$ [28]. It is home to 19,164 people with various ethnicities. Due to agribusiness opportunities here, people from various parts of the country come to this area. Agriculture employs about $80 \%$ of the population. Crop farming, livestock breeding, and fish culture mainly constitute their livelihood. Rice, maize, vegetable farming and fruits (e.g., mangoes) are produced all year round by irrigation from Bagre dam reservoir [29].

\section{MATERIALS AND METHODS}

Much of our discussion below is based on the data we collected from our questionnaire survey in Ghana and Burkina Faso. We conducted the field survey between 1 December 2019 and 30 January 2020. We applied simple random sampling and administered the questionnaire among 150 individuals (50 from each community) in Ghana. In Burkina Faso, 90 individuals (30 from each community) were targeted. Altogether, we collected effective answers from 238 respondents. The response rate was 100\% in Burkina Faso and $99 \%$ in Ghana. Due to the limited reading and writing skills of our respondents, we obtained cooperation from the Ministry of Food and Agriculture personnel in local stations as enumerators. Also, to overcome language barrier, we translated our questions from English into Mossi and Kussal for our respondents in Burkina Faso and Ghana, respectively.

Israel [31] provides a simplified equation for calculating sample sizes. For a 95\% confidence level and an estimated proportion of an attribute present in the population,

$$
\mathrm{p}=0.5 ; \mathrm{n}=\mathrm{N} / 1+\mathrm{N}(\mathrm{e})^{2}
$$

where $\mathrm{n}=$ sample size, $\mathrm{N}=$ population size, and $\mathrm{e}=0.05$, the level of precision.

For a total population of 309,281 people in our study area, the sample size, $n=399$ respondents. The sample size was, however, dependent on the number needed for data analysis. Israel [31] notes that a sample size between 200 and 500 is necessary for multiple regression, an analysis of covariance and log-linear analysis but nearly any sample size suffices for descriptive statistics like frequencies, mode and Chi-squared.

The questionnaire had two parts. The first part was designed to clarify socio-demographic characteristics of the respondents. The second part focused on water governance perceptions by using a set of Likert-type statements and questions. Boone and Boone [32] distinguished Likert-type statements from Likert-scale statements. Likert-type statements are single questions without an intension to combine responses into a composite scale. A Likert-scale, however, comprises four or more Likert-type statements that are to be combined into a single composite score. In total 10 items comprising five statements and five questions constituted 
the second part of the questionnaire (Table 1). These statements were revolved around four key governance principles: public participation, transparency, gender equity and regulatory quality. The five-point Likert-scale we used to assess the degree of public participation and gender equity in decision-making asked the respondents to select the degree of their agreement or opinion to given statements. To assess the level of transparency, five-point Likert-scale questions had choices that ranged from "not easy at all" to "very easy". To rate efforts made by water managers, five-point Likert-scale questions asked the respondents to choose from "very low" to "very high". In assessing regulatory quality, we first assessed respondents' knowledge about local governance authorities responsible for water governance by using list of institutions to choose. We then asked respondents to rate their level of satisfaction.

Table 1: Governance principle and Likert-type statements.

\begin{tabular}{|l|l|}
\hline Governance principles & Questions and statements \\
\hline \multirow{5}{*}{ Public participation } & $\begin{array}{l}\text { (1) My community is sufficiently involved in the decision- } \\
\text { making }\end{array}$ \\
\cline { 2 - 3 } Gender equity & $\begin{array}{l}\text { (2) Customs, religion, and norms of my community are } \\
\text { recognized }\end{array}$ \\
\cline { 2 - 3 } Transparency & $\begin{array}{l}\text { (3) My community has an avenue for receiving complaints or } \\
\text { raising suggestions about basin }\end{array}$ \\
\hline \multirow{5}{*}{ Regulatory quality } & $\begin{array}{l}\text { (1) Women and men have equal participation in decision } \\
\text { making }\end{array}$ \\
\cline { 2 - 2 } & $\begin{array}{l}\text { (2) Women and men have equal access to benefits from this } \\
\text { basin }\end{array}$ \\
\hline $\begin{array}{l}\text { (1) How easy to access information about spillage of excess } \\
\text { Bagre dam water? }\end{array}$ \\
\cline { 2 - 2 } & $\begin{array}{l}\text { (2) How easy institution makes processes of decision making } \\
\text { about water governance in the basin? }\end{array}$ \\
\cline { 2 - 3 } & $\begin{array}{l}\text { (3) How will you rate water manager's efforts to make } \\
\text { stakeholders understand decision making process? }\end{array}$ \\
\hline & $\begin{array}{l}\text { (1) Who manages the Volta River Basin? } \\
\text { (2) How satisfied are you with the regulatory performance of } \\
\text { enforcing agencies? }\end{array}$ \\
\hline
\end{tabular}

Largely agreeing with Boone and Boone [32], we use descriptive statistics as an appropriate method to discuss the results from Likert-type statement questions. The Pearson Chi-squared $\left(\chi^{2}\right)$ was used to understand correlations between respondents' sociodemographic characteristics and their perceptions about governance performance [33]. Null hypothesis $\left(\mathrm{H}_{0}\right)$ was that there is no significant difference between respondents' sociodemographic characteristics and their perceptions about governance performance. $\mathrm{H}_{\mathrm{o}}$ was tested at 0.05 level of significance and was rejected if the p-value is lower than the significance level. However, when the p-value is higher than the significance level, then we accept $\mathrm{H}_{\mathrm{o}}$. We further used stack bar graphs to visualize the result of the survey. The stack bar graph plots responses with each row showing percentage breakdown at each step of the 
Likert scale. An agreement with Likert-type statement is represented by a bar above zero [34]. The mode represents the response with the highest occurrence on a scale of 1 (strongly disagree) to 5 (strongly agree). SPSS version 23 and Statgraphics 18 aided data analysis.

\section{RESULTS AND DISCUSSION}

\subsection{Socio-demographic characteristics of respondents}

As mentioned above, we obtained 238 valid responses in the survey, of which 148 were from Ghana and 90 were from Burkina Faso. The mean age of the Ghanaian respondents was 39.7 years old and that in Burkina Faso was 40.5 years old. In Ghana, 36\% of the respondents were between 18 and 39 years old, and $57 \%$ was between 40 and 59 years old. On the contrary, in Burkina Faso, 53\% belonged to 18-39 age bracket and 37\% to 40-59 age bracket. These results imply that although the mean age in the two countries did not show much difference, more Ghanaian respondents tended to be older than those in Burkina Faso. Only $43 \%$ and $40 \%$ of the respondents in Ghana and Burkina Faso had some form of education (Table 2).

Our survey also revealed that $90 \%$ of the respondents in Ghana had lived close to the Volta River for 11 to 40 years whereas $63 \%$ did so in Burkina Faso (Table 2).

Table 2: Socio-demographic characteristics of respondents.

\begin{tabular}{|c|c|c|c|}
\hline \multicolumn{2}{|c|}{ Socio-demographics } & Burkina Faso & Ghana \\
\hline \multirow{5}{*}{ Age } & $18-29$ & $18(20 \%)$ & $9(6 \%)$ \\
\hline & $30-39$ & $30(33 \%)$ & $44(30 \%)$ \\
\hline & $40-49$ & $19(21 \%)$ & $53(36 \%)$ \\
\hline & $50-59$ & $14(16 \%)$ & $32(21 \%)$ \\
\hline & $60+$ & $9(10 \%)$ & $10(7 \%)$ \\
\hline \multirow{2}{*}{ Gender } & Male & $45(50 \%)$ & $97(66 \%)$ \\
\hline & Female & $45(50 \%)$ & $51(34 \%)$ \\
\hline \multirow{5}{*}{ Education } & No formal education & $55(60 \%)$ & $84(57 \%)$ \\
\hline & Primary & $18(20 \%)$ & $24(16 \%)$ \\
\hline & Junior high school & $9(10 \%)$ & $18(12 \%)$ \\
\hline & Senior high school & $4(5 \%)$ & $17(11 \%)$ \\
\hline & Tertiary education & $4(5 \%)$ & $5(4 \%)$ \\
\hline \multirow{5}{*}{ Occupation } & Artisan & $2(2 \%)$ & $0(0 \%)$ \\
\hline & Farmer & $63(70 \%)$ & $146(98 \%)$ \\
\hline & Student & $3(3 \%)$ & $1(1 \%)$ \\
\hline & Teacher & $6(7 \%)$ & $0(0 \%)$ \\
\hline & Trader & $16(18 \%)$ & $1(1 \%)$ \\
\hline \multirow{6}{*}{$\begin{array}{l}\text { Years of residency } \\
\text { in the study area }\end{array}$} & $5-10$ & $9(10 \%)$ & $55(37 \%)$ \\
\hline & $11-20$ & $50(55 \%)$ & $55(37 \%)$ \\
\hline & $21-30$ & $24(27 \%)$ & $17(11 \%)$ \\
\hline & $31-40$ & $7(8 \%)$ & $14(10 \%)$ \\
\hline & $41-50$ & $0(0 \%)$ & $3(2 \%)$ \\
\hline & $51-60+$ & $0(0 \%)$ & $4(3 \%)$ \\
\hline \multicolumn{2}{|l|}{ Total } & $90(100 \%)$ & $148(100 \%)$ \\
\hline
\end{tabular}




\subsection{Governance performance}

To understand respondents' level of public participation in the Volta River Basin, we asked the respondents to respond to three statements (Table 1). The first statement was "my community is sufficiently involved in decision-making". The second statement was "customs, religion and norms of my community are recognized". The third statement was "my community has an avenue for receiving complaints or raising suggestions about the basin".

In response to the first statement, $24 \%$ of the respondents in Ghana agreed whereas $49 \%$ disagreed. In Burkina Faso, the results are somewhat different as $42 \%$ agreed and only $17 \%$ disagreed. About the second statement, $78 \%$ of the respondents in Ghana disagreed whereas $34 \%$ of the Burkina Faso respondents did so. Another 34\% agreed with the statement. About the third statement, $52 \%$ in Ghana disagreed whereas $29 \%$ did so in Burkina Faso (Fig. 2). This means that the Ghanaian respondents tended to feel alienated from decision-making processes in connection to Volta River governance. Chi-squared analyses on these results revealed that although the Burkina Faso respondents tended to have higher participation than those in Ghana, gender disparity was observed. In Burkina Faso, more men (55\%) agreed with the first statement. Regarding the third statement, more women (54\%) agreed.

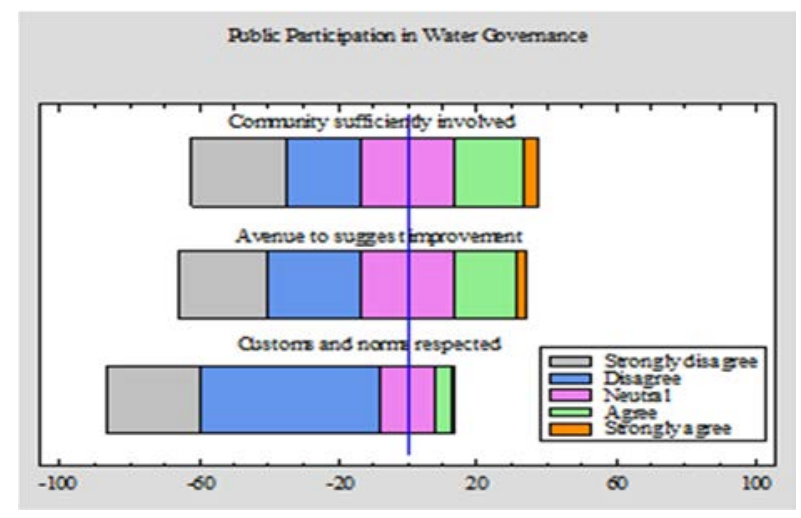

Figure 2: Public participation, Ghana.

To understand respondents' opinion about gender equity in the Volta River Basin, we posed two statements (Table 1): (1) "women and men have equal opportunity in decision making" and (2) "women and men have equal opportunity in sharing benefits". In response to the first statement, $72 \%$ of the respondents in Ghana disagreed whereas $78 \%$ in Burkina Faso did so. About the second statement, 54\% in Ghana and 82\% in Burkina Faso disagreed (Fig. 3). Chi-squared analyses on these results, however, did not show significant difference among women and men. These results suggest that the respondents in both countries largely acknowledged gender inequity in water governance.

To understand respondents' opinion about governance transparency, we asked three questions (Table 1): (1) "how easy was it to access information about spillage of Bagre dam water?"; (2) "how is it easy to understand decision-making processes about water governance?"; and (3) "how will you rate efforts made by water managers to make stakeholders understand the decision-making process?" In response to the first question, 53\% 


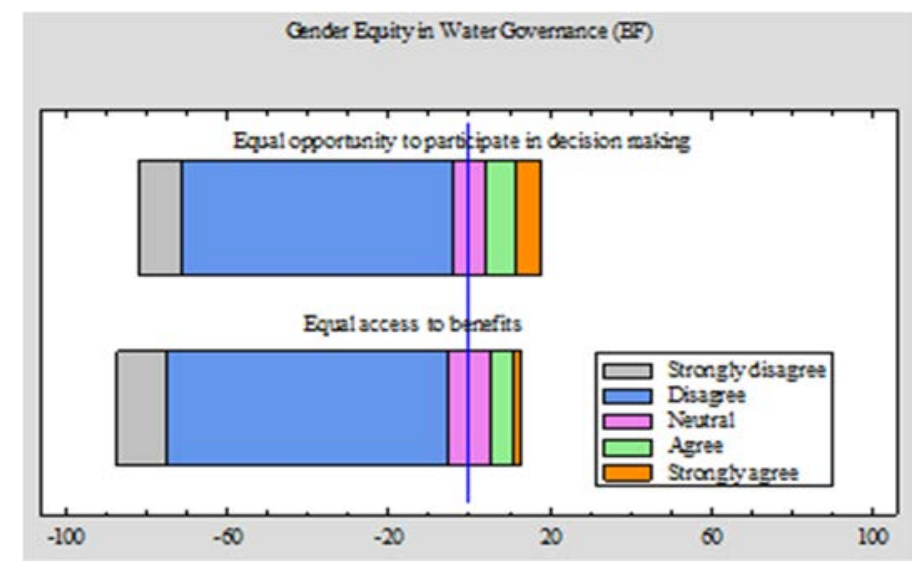

Figure 3: Gender equity, Burkina Faso.

of the respondents in Ghana found it easy to obtain information about spillage while $35 \%$ of them felt that it was difficult. In Burkina Faso, 59\% of the respondents thought that it was difficult to access information whereas $15 \%$ of them did not think so. About the second question, $55 \%$ in Ghana found it easy to understand decision-making processes whereas In Burkina Faso, only $12 \%$ of the respondents found decision making process easy to understand while $63 \%$ of them was not sure. Regarding the third statement, $49 \%$ in Ghana highly rated water managers' performance whereas $64 \%$ in Burkina Faso rated low. These results show different perceptions about water governance between Ghana and Burkina Faso. Although the Ghanaian respondents tended to indicate the existence of governance transparency, our Chi-squared analysis revealed gender disparity about the second and the third statements among the respondents. We found that more men agreed with the second (72\%) and third $(68 \%)$ statements. This may be due to the patriarchal nature of the riparian communities of the Volta Basin where men dominate in public engagements.

To understand respondents' opinion about regulatory quality in the Volta River Basin, we asked two questions (Table 1): (1) "who manages the Volta River Basin?" and (2) "how will you rate the regulatory performance of water managers?" For the first question, six multiple choice answers were presented for the respondents to identify relevant institutions. These institutions are the Volta Basin Authority, Water Resource Commission in Ghana, Ministry of Water and Sanitation in Burkina Faso, Department of Water and Sanitation in Ghana, and the Forestry and Agriculture departments in both countries. The second question used a fivepoint Likert-scale ranging from "very dissatisfied" to "very satisfied".

In response to the first question, $57 \%$ of the respondents identified the Department of Agriculture. Also, about $45 \%$ chose the water resource commission. In Burkina Faso, the Ministry of Water was chosen by $40 \%$ of the respondents. Another $12 \%$ chose the Forestry Department. In stark contrast to the Ghanaian counterpart, only $9 \%$ chose the Department of Agriculture. Agricultural departments in the study areas inform farmers about good water management practices, but they are not responsible for managing water resources of the Volta River. In Ghana, the water resource commission, which was established by an Act of Parliament (Act 522 of 1996), is responsible for managing Ghana's water resources [35]. In Burkina Faso, the Ministry of Water and Sanitation is responsible for water governance [36].

Regarding the second question about rating regulatory performance, 58\% of the respondents in Ghana were satisfied, whereas $36 \%$ of them thought otherwise. In Burkina 
Faso, $54 \%$ of them were dissatisfied while $23 \%$ were satisfied with regulatory quality provided by water managers in the basin.

\section{CONCLUSIONS}

This paper examined riparian communities' water governance perceptions with particular emphasis on possible sources of rising tensions over the use of Volta River water. By using the questionnaire survey, it attempted to understand the perceptions about degrees of their public participation, gender equity, transparency, and regulatory quality.

Regarding public participation, our results revealed that the respondents generally had experienced limited levels of participation in water governance though the Burkina Faso respondents tended to show higher satisfaction level compared to those in Ghana. A large percentage of the Ghanaian respondents particularly had problems with discrimination against religion and norm in decision-making processes as they were minority Muslim people where Christianity tends to dominate Ghanaian society in general. As a result, $52 \%$ of the Ghanaian respondents felt being left out from governance whereas 39\% in Burkina Faso, especially among males, felt involved in improving governance. The respondents generally acknowledged the existence of gender inequity in both countries.

With respect to transparency, the Ghanaian respondents tended to find that they had somewhat sufficient information about water governance. Regarding their access to information about Volta River water use, easiness to understand water governance processes, and water managers' performance, $45-55 \%$ of the respondents in Ghana answered favorably. In Burkina Faso, however, 59-65\% of the respondents had negative perceptions about these transparency related issues.

This result, however, must be placed in a context of how the respondents understood water governance responsibilities among authorities. In Ghana $57 \%$ had a wrong perception and thought that the Agricultural Department was responsible for the Volta River Basin management. Only $45 \%$ knew correctly that the water resource commission was responsible. In Burkina Faso, $40 \%$ of the respondents knew that the Ministry of Water was responsible for managing water in the Basin.

These results, overall, suggest a further need to communicate and equitably engage with local communities about water governance. As most of the respondents and local communities in the Volta River Basin in general depend on agriculture for livelihoods, it may not be easy for them to distinguish water governance from agricultural activities. Flooding from Bagre dam spillage is another concerning issue for those who engage in farming along the Volta River, where they tend to expect agricultural authorities to mitigate. Although our survey was not designed to find cross-border communication efficiency, this is another topic to be explored with detail in the future in order to alleviate rising international tensions over water management in western Africa.

\section{ACKNOWLEDGEMENT}

We express profound gratitude to the 238 riparian community members in Ghana and in Burkina Faso who cooperated with us and provided information for this research during our field survey.

\section{REFERENCES}

[1] FAO, Global framework on water scarcity in agriculture. Report of Committee on Agriculture, COAG/2018/9, Twenty-sixth Session, Rome, 2018. 
[2] Judeh, T., Haddad, M. \& Özerol, G., Assessment of water governance in the West Bank, Palestine. International Journal of Global Environmental Issues, 16(1/2/3), pp. 119-134, 2017.

[3] UNDP, User's Guide on Assessing Water Governance. Governance Centre: Oslo, 2013.

[4] Woodhouse, P. \& Muller, M., Water Governance: An historical perspective on current debates. World Development, 92, pp. 225-241, 2017.

DOI: 10.1016/j.worlddev.2016.11.014.

[5] World Water Assessment Program, Water for People Water for Life. UNESCOWWAP, pp. 4-6, 2003. https://unesdoc.unesco.org/ark:/48223/pf0000129556. Accessed on: 11 Feb. 2021.

[6] FAO, Water governance for agriculture and food security. Report on Committee on Agriculture, COAG/2014/6, Twenty-fourth Session, Rome, 2014.

[7] Global Water Partnership, Effective water governance: Learning from the dialogues. GWP Secretariat, Stockholm, 2003.

[8] Rogers, B.P. \& Hall, A.W., Effective water governance. GWP Technical Committee (TEC) Background Paper, No. 7, 2003.

[9] Adhikari, B. \& Tarkowski, J., Examining water governance: A new institutional approach. Journal of Geography and Natural Disaster, 3(2), pp. 1-10, 2013.

[10] Batchelor, C., Water governance literature assessment. International Institute for Environment and Development (IIED), 2523, 2007.

[11] Ganoulis, J. \& Fried, J., Transboundary Hydro-Governance: From Conflict to Shared Management. Springer, 2018.

[12] Lautze, J., De Silva, S., Giordano, M. \& Sanford, L., Putting the cart before the horse: Water governance and IWRM. Natural Resources Forum, 35(1), pp. 1-8. 2011.

[13] Kaufmann, D., Kraay, A., \& Zoido, P., Governance matters. World Bank policy research working paper, No. 2196, 1999. https://papers.ssrn.com/sol3/papers.cfm? abstract_id=188568. Accessed on: 5 May 2020.

[14] Hanasz, P., A little less conversation? Track II dialogue and transboundary water governance. Asia and the Pacific Policy Studies, 4(2), pp. 296-309, 2017. DOI: 10.1002/app5.183.

[15] Ampomah, B.Y., Adjei, B.A. \& Youkhana, E., The transboundary water resources management regime of the Volta Basin. ZEF Working Paper Series, No. 28, 2008.

[16] Gao, Y. \& Margolies, A., Transboundary water governance in the Volta River Basin, 2009. https://wikis.uit.tufts.edu/confluence/display/aquapedia/Transboundary+Water + Governance + in + the+Volta+River+Basin. Accessed on: 2 May 2020.

[17] World Bank, Project appraisal document on proposed grants to the Volta Basin Authority from the cooperation in international waters in Africa for a Volta River Basin strategic action programme implementation project. Global Water Practice (GWADR), Africa Region, 2015.

[18] Yankey, I. K., Ghana's water relations with Burkina Faso: Hydropolitical standpoint. Master's thesis, Sosyal Bilimler Enstitüsü, 2019.

http://www.openaccess.hacettepe.edu.tr:8080/xmlui/handle/11655/6050. Accessed on: 2 May 2020.

[19] Schulte-Wülwer-Leidig, A., Gangi, L., Stötter, T., Braun, M. \& Schmid-Breton, A., Transboundary cooperation and sustainable development in the Rhine Basin. Achievements and Challenges of Integrated River Basin Management, Intechopen, pp. 123-147, 2018. 
[20] Paul, F.J.E., Francesc, R., Windekind, C.B., Mark, H., Troy, D.G. \& McCutcheon, B., Good governance in protected areas: an evaluation of stakeholders' perceptions in British Columbia and Ontario Provincial Parks. Journal of Sustainable Tourism, 21(1), pp. 60-79, 2013. DOI: 10.1080/09669582.2012.671331.

[21] Mahon, R., Fanning, L. \& McConney, P., Assessing governance performance in transboundary water systems. Environmental Development, 24(Nov. 2017), pp. 146$155,2017$.

[22] Jacobson, M., Fiona, M., Ingvild, O., Paavani, R. \& Håkan, T., User's guide on assessing water governance. United Nations Development Programme (UNDP), Phoenix Design Aid, Denmark, 2013.

[23] Ghana Statistical Service - Bawku Municipality, District analytical report - Bawku municipality. Population and Housing Census, pp. 1-71, 2014.

http://www.statsghana.gov.gh/docfiles/2010_District_Report/UpperEast/BawkuMuni cipality.pdf.

[24] Ghana Statistical Service - Binduri, District analytical report - Binduri district. Population and Housing Census, pp. 1-79, 2014. https://new-ndpc-static1.s3. amazonaws.com/CACHES/PUBLICATIONS/2016/06/06/Binduri+2010PHC.pdf.

[25] Ghana Statistical Service - Garu, District analytical report - Garu Tempane district. Population and Housing Census, pp. 1-79, 2014. http://www2.statsghana.gov.gh/ docfiles/2010_District_Report/Upper\%20East/GARU\%20TEMPANE.pdf.

[26] Ministry of Food and Agriculture, Facts and figures, 2015. http://agricinghana.com/ wp-content/uploads/2017/07/AGRICULTURE-IN-GHANA-Facts-and-Figures2015.pdf. Accessed on: 11 Dec. 2019.

[27] WikiZER, Bagre dam, 2020. https://www.wikizero.com/en//Bagre_Dam. Accessed on: 14 Jul. 2020.

[28] Global Water Partnership, Capitalizing the development process of the action plan for IWRM and its implementation in Burkina Faso. GWP/WA: Ouagadougou, Burkina Faso, pp. 3-4, 2009.

https://www.gwp.org/contentassets/c9eeff4decf445d3b92bbf52711af009/capitalizing -burkina-iwrm-plan.pdf. Accessed on: 5 Nov. 2019.

[29] City population, 2020. https://citypopulation.de/php/burkinafaso-communes-admin. php?adm2id=BF480101. Accessed on: 15 Apr. 2020.

[30] IUCN, Improving water governance in the Volta Basin-Phase 2, PAGEV (2), 2009. https://www.iucn.org/sites/dev/files/import/downloads/pagev_ii.pdf. Accessed on: 9 Aug. 2020.

[31] Israel, G.D., Determining sample size. Fact sheet PEOD-6, University of Florida, pp. $1-5,1992$.

[32] Boone, H.N. \& Boone, D.A., Analyzing Likert data. Journal of Extension, 50(2), pp. $1-5,2012$.

[33] Kent State University Libraries, SPSS tutorials: Chi-square test of independence. 2020. https://libguides.library.kent.edu/SPSS/ChiSquare. Accessed on: 26 Apr. 2020.

[34] Statgraphics18, Likert plot, 2017. http://cdn2.hubspot.net/hubfs/402067/PDFs/ Likert_Plot.pdf. Accessed on: 13 Aug. 2020.

[35] Water Resource Commission, About WRC, 2020. http://www.wrc-gh.org/. Accessed on: 14 Jul. 2020.

[36] International Water and Sanitation Centre (IRC), Burkina Faso creates new ministry for water and sanitation, 2013. https://www.ircwash.org/news/burkina-faso-createsnew-ministry-water-and-sanitation-1. Accessed on: 14 Jul. 2020. 